\title{
A RELAÇÃO ENTRE DIREITO INTERNO E DIREITO INTERNACIONAL: OS IMPACTOS NO COTIDIANO JURÍDICO BRASILEIRO SOB A PERSPECTIVA DA AMPLIAÇÃO DO BLOCO DE CONSTITUCIONALIDADE
}

LUCIANE KLEIN VIEIRA

Doutoranda em Direito Internacional pela Faculdade de Direito da Universidade de Buenos Aires, Professora de Direito Internacional (PUCC/FACAMP). Docente de

Direito da Integração (UBA). Email: Iucianekleinvieira@yahoo.com.br

Luís Renato Vedovato

Doutor em Direito Internacional pela Faculdade de Direito da USP, Professor do Programa de Mestrado em Direito da UNINOVE Email: Irvedovato@gmail.com

\section{Resumo}

A relação entre direito interno e direito internacional, efetivada por decisóes judiciais, é um tema recorrente tanto do direito internacional dos direitos humanos quanto do direito constitucional. $\mathrm{O}$ presente artigo tem como finalidade retratar as interaçóes entre o direito interno e o direito internacional, com ênfase no caso brasileiro, levando em consideração as normas internas e a prática judicial. Para tanto, será utilizado o método dogmático, que envolve a análise das normas relativas ao tema no cenário internacional e interno, com perspectiva empírica, tendo em vista a análise de casos em que a questão foi levantada. Neste tocante, será dada especial ênfase à temática do bloco de constitucionalidade e à sua ampliação derivada da inclusão dos tratados de direitos humanos ratificados pelo Brasil.

\section{Palavras-chave}

Cortes Internacionais; Interação entre Direito Interno e Direito Internacional; Tratados de Direitos Humanos; Bloco de Constitucionalidade.

\section{Abstract}

The relationship between domestic law and international law, carried out by court decisions, is a recurring theme of both international human rights law and constitutional law. This article aims to portray the interactions between domestic law and international 
law, with emphasis on Brazil, taking into account the internal rules and judicial practice. Therefore, we will use the dogmatic method, which involves analyzing the rules on the subject in the international and domestic front, with empirical perspective, with a view to analysis of cases in which the issue was raised, in particular the possible existence constitutionality block and its growth because human rights treaties ratified by Brazil.

\section{Key words}

international courts; Interaction between national law and international law; $\mathrm{Hu}-$ man rights treaties; Constitutionality block.

\section{Introdução}

Um tratamento estritamente teórico da relação entre o direito internacional e o direito interno tem aumentado a sua importância prática, especialmente pelo fato de que essa relação é cada vez mais identificável na teoria, tendo em vista as inúmeras diferenças entre os vários ordenamentos jurídicos. Em outras palavras, dificilmente um Estado segue à risca uma das teorias que tentam explicar essa relação e acaba por criar uma forma específica para construir o diálogo entre direito interno e internacional. Embora o direito internacional esteja se desenvolvendo num ritmo sem precedentes nas últimas décadas, e o direito constitucional tenha perdido seu espaço, como afirmado por Marcelo Neves (2009, p. 38), é fato que as especificidades de cada país tornam mais árduo o trabalho de se criar uma teoria sobre o tema.

O objetivo deste artigo é mais modesto. O que se pretende é lidar com o problema do ponto de vista do direito interno brasileiro, o que exige que sejam analisadas as decisóes do Supremo Tribunal Federal sobre o tema. Isso não significa dizer que as conclusóes dessa Corte são aceitas sem questionamento, o que abre espaço para a crítica pela ótica teórica, principalmente sob a égide do direito comparado.

De fato, o debate ainda faz sentido, pois é possível constatar que há uma tensão inerente à ideia de supremacia constitucional, como é entendido por muitos constitucionalistas, e as pretensões de autoridade, feita pelo direito internacional. Essa tensão foi, por muito tempo, encoberta pelo fato de que o direito internacional, até recentemente, abrangia apenas um campo relativamente restrito, circunscrito às relaçóes internacionais, tendo sido solidamente fundamentado no consentimento do Estado e, geralmente, as questóes relativas à sua interpretação e aplicação eram reservadas aos tribunais internos dos Estados. Porém, hoje, o direito internacional já não se encaixa somente nessa descrição, na medida em que foi adquirindo contornos cada vez mais próximos à relação do Estado com o seu nacional ou com o estrangeiro residente em seu território. 
Nesta seara, o direito internacional ampliou seu escopo, afrouxou sua ligação com o consentimento do Estado e reforçou os mecanismos de adjudicação e de aplicação obrigatória. Não é surpreendente que uma das questôes mais prementes de direito constitucional contemporâneo seja a forma de pensar a relação entre a constituição nacional e o direito internacional. Esse é o ponto que analisaremos no presente artigo, fazendo especial referência aos tratados de direitos humanos e à sua inserção no bloco de constitucionalidade.

\section{As Teorias sobre a Relação entre Direito Interno e Internacional}

Nas primeiras décadas do século 20, os debates entre os juristas que pensavam sobre a relação entre o direito nacional e internacional se focavam em saber se o mundo exibia estrutura monista ou dualista. Sob uma concepção monista do mundo, o direito internacional e o direito nacional constituem uma ordem jurídica verticalmente integrada, em que o direito internacional é colocado num patamar superior. Vale dizer aqui, como será analisado mais adiante, que há variaçóes entendidas como correntes monistas, todavia, as bases teóricas do monismo ficam comprometidas naquelas situações em que o direito interno é colocado em posição hierárquica superior ao direito internacional, pois, em ocorrendo o conflito, ressurgem dois ordenamentos jurídicos, o interno e o internacional, que contêm o tratado que, apesar da decisão interna vinculada à hierarquia, ainda vincula o Estado.

Por outro lado, os dualistas defendem a possibilidade conceitual, a realidade histórica e a condução normativa de uma concepção não-monista do mundo jurídico (Kumm, 2009). Sob uma concepção dualista, há diferentes sistemas jurídicos no mundo em níveis nacional e internacional, que interagem uns com os outros com base nas normas internas de cada sistema jurídico.

No entanto, no período inicial do século XX, o debate era simplificado por conta de haver, como dito anteriormente, um direito internacional quase totalmente situado em um campo específico, que não se chocava com o direito nacional. Assim, o avanço do direito internacional fez com que choques normativos se tornassem cada vez mais comuns, fazendo surgir a necessidade de se debater tal relacionamento, pois, dificilmente, há área do direito que não seja regulada por normas internacionais.

Nesse cenário, a interação entre as normas internacionais e as normas internas dos Estados é constantemente discutida na doutrina e na jurisprudência. Assim, é necessário lembrar-se dos conflitos entre tratados e normas internas, como é o caso da prisão do depositário infiel, que é permitida pelo texto do art. 5º LXVII, da Constituição Federal, e proibida pelo art. 7o, 7, do Pacto de San José da Costa Rica, tratado internacional do qual o Brasil faz parte (Soares, 2004, p. 110), o que foi superado apenas após o julgamento do 
RE 466.343-SP, em que se definiu, como será visto, a hierarquia supralegal dos tratados de direitos humanos ${ }^{1}$.

Por sua vez, o dualismo separa dois ordenamentos jurídicos e defende não haver tal interaçáo, sendo necessária a internalização da norma, via de regra, do tratado, para que possa ser aplicada internamente, enquanto que, para o monismo, há um ordenamento jurídico único, do qual fazem parte as normas internas e as normas internacionais. Nesse caso, como o tratado é a novidade, há que se identificar a hierarquia do tratado internacional.

Concretamente, com a publicação, em 1920, da obra de Karl Heinrich Triepel (1920), construída no curso da Academia da Haia, em 1899, sobre as relaçóes entre o direito internacional e o direito interno (Triepel, 1920), iniciou-se uma discussão doutrinária sobre a temática.

Em sua obra, Triepel defende o dualismo e para isso parte de duas premissas básicas: em primeiro lugar, diz que os dois ordenamentos nascem de fontes distintas; em segundo lugar, para ele, o direito internacional regula relaçóes diversas daquelas disciplinadas pelo direito interno (Morelli, 1955, p. 46), o que atualmente já não se sustenta.

Os partidários do dualismo (Barile, 1957, p. 18), dessa forma, pregam que não pode haver nenhum tipo de conflito entre normas internas e normas internacionais, pois elas estão em ordenamentos distintos e incomunicáveis. Assim, tais normas não teriam o mesmo objeto e não se prestariam a regular as mesmas relaçóes sociais.

Em nenhum momento, no entanto, os dualistas pregavam a incoerência na atitude dos Estados, pois o não cumprimento de um tratado internacional continuava levando à responsabilização do Estado no cenário internacional (Balladore-Pallieri, 1962, p. 32). Valendo lembrar que tal teoria dava munição para o argumento que sustentava a incoerência (Shaw, 1995, p. 35).

Segundo a teoria dualista, para que as normas veiculadas em um tratado internacional possam ser aplicadas internamente, é necessário que se faça a sua veiculação por meio de instrumento interno, como, por exemplo, lei ordinária, decreto, resolução, etc. As normas do tratado, para o dualismo puro, portanto, devem enfrentar novo processo legislativo, já que necessitam de um ato normativo de transposição, internalização ou incorporação.

Como não há possibilidade de conflito entre norma interna e norma internacional, para a teoria dualista, não há que se falar em hierarquia do tratado na ordem interna, a hierarquia será a do instrumento normativo pelo qual for veiculado.

1 Para um aprofundamento no tema, vale a leitura do voto do Min. Celso Mello proferido no HC 87.5858 , de 12 de março de 2008. 
Por sua vez, os monistas ${ }^{2}$, encabeçados por Kelsen, defendem que a unidade do sistema deve ser resguardada ${ }^{34}$. Neste sentido, conforme Nguyen Quoc Dinh, Patrick Dailler e Alain Pellet (1999, p. 85), "a teoria monista sustenta que o direito internacional se aplica directamente na ordem jurídica dos Estados, porque suas relações são relações de interpenetração, tornadas possíveis por pertencerem a um sistema único baseado na identidade dos sujeitos (os indivíduos) e das fontes do direito (um fundamento 'objectivo' e não processos que póem em execução a vontade dos Estados)".

No entanto, é importante ressaltar que não é totalmente correta tal afirmação, pois, podem existir casos em que a aplicabilidade direta, como acima destacado, seja impossível, como bem argumenta o professor Thomas Buergenthal. O que deve ser levado em conta é a qualidade de auto-aplicabilidade do tratado internacional, não importando, para tanto, o fato do país ser ou não monista (Buergenthal, 1992).

Se um tratado é ou não auto executável (self-executing), é uma questão de direito internacional. $\mathrm{O}$ direito interno determinará se o tratado cria direitos que podem ser invocados nos tribunais internos diretamente, o que se destina exclusivamente aos países monistas.

Há ainda os que defendem que, nos países monistas, há a necessidade de se analisar a hierarquia do tratado internacional. Porém, mais uma vez, destaca-se que o monismo só existe no caso de supremacia do direito internacional, nos demais casos, as duas ordens jurídicas surgirão toda vez que o direito internacional estiver em patamar hierárquico inferior. Não obstante, para os que defendem que mesmo assim há monismo, há três correntes a serem analisadas:

- Supremacia do direito internacional;

- Supremacia do direito interno; e

- Supremacia constitucional.

Para os que entendem haver monismo, o que pode ser chamado de monismo ampliado, em todas as hipóteses acima, o ordenamento interno do país monista permitiria o conflito entre norma interna e norma internacional, portanto, seria ele apto para

2 BARILE, Giuseppe. Diritto Internazionale e Diritto Interno. Milano: Giuffrè; 1957, pg. 86: "La tesi monista dei rapporti fra diritto internazionale spontaneo e diritti interni non scritti, che si è venuta esponendo nelle sue linee teoriche, verrà ora vagliata al lume dell'esperienza giuridica costituita dalla giurisprudenza dei paesi anglo-sassoni."

3 Sobre monismo e dualismo, confira-se REUTER, Paul. Droit International Public. Paris: Presses Universitaries de France; 1973 e ROUSSEAU, Charles. Droit International Public - 5 vol. Paris: Sirey; 1970 .

4 Para uma visáo monista do direito, cf. KELSEN, Hans. Les Rapports de Système entre le Droit Interne et le Droit International. Recueil Des Cours. 1926; 14:227, pg. 227. 
solucionar tal pendência. Destaca-se que não se vê amparo possível nesse ponto de vista, especialmente quando, como acima dito, houver conflito solucionado pela aplicação da norma interna.

Há, ainda, autores que dizem superadas as discussóes entre monistas e dualistas, tendo aparecido teorias conciliadoras, entre as quais se destacam as chamadas doutrinas coordenadoras. No entanto, tais doutrinas podem ser vistas como ramos dentro da teoria monista, como um possível monismo ampliado, apesar de não pregarem a supremacia constante do direito internacional em relação ao direito interno.

Ainda, segundo André de Carvalho Ramos (2013), a força expansiva do direito internacional dos direitos humanos em conjunto com seu "inesgotável fôlego normativo" levam-no ao centro do debate sobre a pluralidade das ordens jurídicas, sendo farta fonte para a doutrina sobre a questão. Deixando claro que isso não foi suficiente para permitir a construçáo de um conjunto normativo para solucionar os conflitos resultantes das interaçóes entre tais ordens.

\section{A Solução Brasileira}

A pergunta central, então, a ser respondida é: como o ordenamento jurídico brasileiro "encara" as normas internacionais, especialmente as normas de direitos humanos?5 Logo, o ponto fulcral é definir qual a hierarquia delas no ordenamento jurídico interno, depois de incorporadas.

Como anteriormente exposto, o debate entre monistas e dualistas é de suma importância (Brownlie, 1990, p. 210) para se compreender exatamente o procedimento para sua revogação, podendo-se, em última análise, até mesmo, dizer-se que, nos países monistas, a desvinculação do país de um tratado internacional é pressuposto para que a norma dele proveniente seja revogada.

Invariavelmente, entra em discussão a possibilidade de violação da soberania do Estado quando se levanta a hipótese de prevalência do tratado sobre a Constituição (Carvalho Ramos, 2013). Mas, deve-se ter presente que o direito internacional tem como principal característica o consentimento, ou seja, nenhum país se vincula, em tese, a um tratado se assim não desejar (Malanczuk, 1998, p 47). Além disso, especificamente no que diz respeito aos direitos fundamentais, a sua internacionalização pode evitar exageros totalitários ou pressóes econômicas internas. Realmente, a internacionalizaçáo da proteção dos direitos fundamentais traz benefícios incomensuráveis aos indivíduos, criando mais uma fonte de proteção contra atos ou, como no presente caso, omissões do Estado. Além de

5 Sobre a internacionalização dos direitos humanos ver: AMARAL JÚNIOR, Alberto do. Curso de Direito Internacional Público. 5a ed. São Paulo: Atlas, 2015. pp. 507-510. 
trazer à tona a sua força contramajoritária, que permite abafar os excessos eventualmente cometidos por grupos dominantes.

O posicionamento do Supremo Tribunal Federal, que é o que soa mais forte nesse tema, deve ter uma posição de destaque, não isenta de críticas, cabendo, para tanto, uma pequena avaliação histórica. O STF definiu, no passado, que o tratado internacional assumia a hierarquia de lei ordinária federal, sendo válida a regra de que lei posterior revoga lei anterior. Foi o decidido, na década de 70 do século XX, no Recurso Extraordinário (RE) n. 80.004. Pelo decidido nesse julgado, é possível que um tratado deixe de ser aplicado quando colida com uma lei ordinária, que lhe seja posterior.

No entanto, como ensina Karl Engisch, há a necessidade de se entender às mudanças mundiais e nacionais, antes de apenas aplicar o direito do mesmo modo que é aplicado no âmbito interno, devendo-se abrir caminho, pois "constitui um privilégio quase exclusivo da ciência jurídica, entre as outras ciências da cultura, o facto de ela não abrir caminho ao lado ou atrás do direito, mas, antes, poder afeiçoar o direito mesmo e a vida que nele e sob a sua égide decorre"(Engisch, 1996, p. 13). Dessa forma, o STF também avançou trazendo relevantes novos posicionamentos.

Neste diapasão, em 2008, o STF deu destaque especial aos tratados de direitos humanos, alçando-os ao patamar de normas supralegais, ou seja, na posição intermediária entre a Constituição e as leis federais. De fato, no julgamento do Recurso Extraordinário 466.343-1- SP, o Min. Gilmar Mendes votou no sentido de que: "O status normativo supralegal dos tratados internacionais de direitos humanos subscritos pelo Brasil, dessa forma, torna inaplicável a legislação infraconstitucional com ele conflitante, seja ela anterior ou posterior ao ato de ratificação."

Destaca-se que ainda se está no campo dualista, pois, caso um tratado de direitos humanos seja contrário à Constituição Federal, ainda será possível declarar-se a inconstitucionalidade dele. Caso isso aconteça, o Brasil continuará vinculado na ordem internacional, mas o tratado não poderá ser aplicado internamente, o que faz nascer o cenário de dois ordenamentos jurídicos distintos, base para a teoria dualista e para o sistema de incoerências.

Celso Lafer (2005, p. 15-18), apesar de se referir apenas aos tratados anteriores à $\mathrm{CF} / 88$, defende que:

Com efeito, entendo que os tratados internacionais de direitos humanos anteriores à Constituição de 1988, aos quais o Brasil aderiu e que foram validamente promulgados, inserindo-se na ordem jurídica interna, têm a hierarquia de normas constitucionais, pois foram como tais formalmente recepcionados pelo $\$ 2^{\circ}$ do art. $5^{\circ}$ náo só pela referência nele contida aos tratados como também pelo dispositivo que 
afirma que os direitos e garantias expressos na Constituição não excluem outros decorrentes do regime e dos princípios por ele adotados.

Vai além o Min. Celso de Mello, reconhecendo, em voto proferido no HC 87.5858 - TO, hierarquia materialmente constitucional aos tratados internacionais de direitos humanos aos quais o Brasil se vinculou:

Após muita reflexão sobre esse tema, e não obstante anteriores julgamentos desta Corte de que participei como Relator (RTJ 174/463-465 - RTJ 179/493-496), inclino-me a acolher essa orientaçáo, que atribui natureza constitucional às convençôes internacionais de direitos humanos, reconhecendo, para efeito de outorga dessa especial qualificação jurídica, tal como observa CELSO LAFER, a existência de três distintas situaçóes concernentes a referidos tratados internacionais [...] .

O pleno do STF seguiu a posição do Min. Gilmar Mendes, segundo a qual os tratados de direitos humanos aprovados pelo rito simples (antes ou depois da Emenda Constitucional 45, de 08 de dezembro de 2004) possuem hierarquia supralegal, enquanto que os tratados de direitos humanos aprovados pelo rito congressual especial, do art. $5^{\circ}$, parágrafo $3^{\circ}$, da CF, teriam hierarquia de emendas à Constituição.

Os demais tratados continuariam a seguir a decisão do RE 80.004, que os coloca como equivalentes a leis federais, dando-lhes, portanto, paridade hierárquica. Sobre esse tema, há que se dizer que, no Recurso Extraordinário 460.320-Paraná, o tema voltará a ser analisado pelo STF, havendo voto já proferido pelo Min. Gilmar Mendes. O processo foi objeto do pedido de vista do Min. Dias Tóffoli, encontrando-se, na atualidade, com seu julgamento adiado, por pedido do ministro referido, desde 30 de setembro de 2014 .

Assim, atualmente, a posição do STF é a de que o ordenamento jurídico brasileiro é dualista moderado, pois, apesar de existir dois ordenamentos, há a necessidade de incorporação do tratado, que é feita por meio de decreto presidencial, conforme decidido no Agravo Regimental em Carta Rogatória n. 8.279-4 (Argentina), no qual ficou plasmado ser fundamental o decreto presidencial para que a norma internacional passe a pertencer ao ordenamento jurídico brasileiro.

Portanto, na visão dualista da Corte suprema, os tratados em geral são equivalentes a leis federais, enquanto que os tratados de direitos humanos, podem ser supralegais ou equivalentes a emendas à Constituição, conforme o caso. Outra exceção é aplicada para os tratados internacionais de direito tributário, que, por força do art. 98 do Código Tributário Nacional, têm hierarquia supralegal, ${ }^{6}$ havendo sido este dispositivo recepcionado pelo Superior Tribunal de Justiça (REsp 21989 SP 1992/0010752-4).

6 Sobre o tema ver: VIEIRA, Luciane Klein. "La incorporación de los tratados internacionales al orden jurídico interno de Brasil”. In: NEGRO, Sandra (Dir.) Evolución Jurídico-Institucional. Derecho de la Integración. Manual. Parte II América-África. Buenos Aires: BdeF, 2012. p. 203. 
No entanto, deve ser ressaltado, como já exposto por André de Carvalho Ramos (2009), que o diálogo das Cortes é mais importante que o debate sobre a hierarquia das normas, pois, dessa forma, não se ignoram os intérpretes internacionais.

De fato, o direito internacional ${ }^{7}$ tem avançado e, por conta disso, ocupado, nos últimos tempos, espaços que antes eram claramente destinados ao contingente normativo interno. É o que se pode empiricamente constatar ao se analisar qualquer ramo específico do direito, que, inevitavelmente, contará com normas internacionais, pois, o direito internacional se expande de forma constante, porém, com intensidade variável, o que se consubstancia em diferenças no tocante à implementação das normas. De fato, tal expansão não é acompanhada de uma homogeneidade no que se refere à aplicação do direito internacional. Em outras palavras, por mais que se possa constatar que os vários aspectos da vida do indivíduo e da atuação do Estado estejam passando por normatização internacional, a imperatividade desses dispositivos não é uniforme, alcançando maior efetividade em áreas ligadas ao comércio internacional e às normas de jus cogens, passando por sensível diminuição em áreas como proteção ambiental e certos aspectos de direitos humanos.

Segundo Shaw (2011, p. 101) $)^{8}$, com o avanço das tecnologias, especialmente de comunicações, a soberania foi profundamente alterada, por conta da interdependência entre os Estados, o que, "aliada à organização cerrada da sociedade comercial e política contemporânea em nível internacional", leva a que todos os atos dos Estados, mesmo internos, tenham reflexos nas relaçóes internacionais e nas decisóes internas de outros Estados.

O direito administrativo, assim, não ficou imune ao direito internacional. De fato, muitos são os tratados internacionais que exigem regulamentação posterior, o que se faz por meio das Conferências das Partes, em claro exercício do poder regulamentar, que permite criar normas vinculantes às naçóes envolvidas ${ }^{9}$. O direito, assim, deve se alterar para enfrentar as mudanças da realidade, como explicitado por José Eduardo Faria (2004, p. 13):

Desde o advento da transnacionalização dos mercados de insumos, produção, capitais, finanças e consumo - que em pouco mais de uma década, transformou radicalmente as estruturas de dominação politica e de apropriação de recursos, subverteu as noçōes de tempo e espaço, derrubou barreiras geográficas, reduziu as fronteiras burocráticas e jurídicas entre naçöes, revolucionou

7 CONFORTI, Benedetto. Diritto Internazionale. 8ª Ed. Napoli: Editoriale Scientifica, 2010, p. 3: "In una prima approssimazione il diritto Internazionale può essere definito come il diritto (o ordinamento) della 'comunità degli Stati'”.

8 SHAW, Malcolm N. Direito Internacional. São Paulo: Martins Fontes, 2011. p. 101.

9 Sobre o Direito Administrativo Internacional ver: STEWART, R. B.; SANCHEZ BADIN, M. R. The World Trade Organization: Multiple Dimensions of Global Administrative Law. International Journal of Constitutional Law, v. 9, n. 3-4, pp. 556-586. doi: 10.1093/icon/mor051, 2011, acesso em 06 de abril de 2012. 
os sistemas de produção, modificou estruturalmente as relaçōes trabalhistas, tornou os investimentos em ciência, tecnologia e informação em fatores privilegiados de produtividade e competitividade, criou formas de poder e influência novas e autônomas e, por fim, multiplicou de modo exponencial e em escala planetária os fluxos de ideias, conhecimento, bens, serviços, valores culturais e problemas sociais - o pensamento jurídico parece encontrar-se numa situação análoga àquela em que se achava o pensamento econômico no término dos tumultuados anos 20; ou seja: frente ao desafio de encontrar alternativas para a exaustão paradigmática de seus principais modelos teóricos e analiticos, tal a intensidade do impacto gerado por todas essas transformaçôes em seus esquemas conceituais, em seus pressupostos epistemológicos, em seus métodos e em seus procedimentos.

Com o crescimento das organizaçóes internacionais e dos tratados, especialmente daqueles que exigem regulamentação posterior, o direito administrativo ultrapassa as fronteiras do Estado e passa a ser influenciado pelo direito internacional na mesma medida.

Apesar do avanço doutrinário, os tribunais brasileiros ainda citam pouco decisóes de tribunais internacionais, o que deve ser o próximo passo no debate da pluralidade das ordens jurídicas. Do mesmo modo, muitas vezes, como se verificou no caso da Guerrilha do Araguaia, decidido pela Corte Interamericana de Direitos Humanos, em 24 de novembro de 2010, o Brasil sequer se preocupa em cumprir com as decisóes provenientes de cortes internacionais às quais se submete à jurisdição.

\section{Os Tratados de Direitos Humanos e o Bloco de Constitucionalidade}

O sistema de direito interno de um país está pautado na supremacia da Constituição Federal, norma que ocupa o ápice da pirâmide kelseniana. Deste modo, todas as normas que não forem de origem constitucional, devem ser compatíveis com a Carta Magna, formal e materialmente, para que possam ser declaradas constitucionais e, assim, conviverem harmonicamente no ordenamento jurídico, depois de haverem passado pelo controle de constitucionalidade. ${ }^{10}$ Em outras palavras, a Constituição é o fundamento de validade das disposiçôes legais inferiores ou subsequentes.

Não obstante, neste sistema, não somente o texto da Constituição, no caso do direito brasileiro, pode servir de parâmetro para o controle de constitucionalidade. A Constituição de 1988 vai muito além disso, ao autorizar, de forma expressa, que normas que estejam fora do seu corpo também possam ser consideradas constitucionais. Neste sentido,

10 Sobre o tema ver: SILVA, Virgílio Afonso da. "O STF e o controle de constitucionalidade; deliberação, diálogo e razão pública”. In: Revista de Direito Administrativo. No 250. 2009. pp. 197-227. 
adverte-se que “já é uma realidade insofismável que as normas constitucionais não estão restritas aos artigos, parágrafos e alíneas integrantes da Constituição Federal de 1988. Assim, decorre a ideia do bloco de constitucionalidade, ${ }^{11}$ o que corresponde ao conjunto de todas as normas e textos com patamar constitucional, ainda que não constantes na constituição codificada." 12

Deste modo, surge o conceito de bloco de constitucionalidade amplo e restrito, entendendo-se pelo primeiro aquele conjunto de atos normativos e princípios expressos ou implícitos que são considerados constitucionais, ainda que não integrem o texto formal da Constituição, ${ }^{13}$ ao passo que o segundo se refere estritamente ao texto escrito da Carta Magna.

De fato, o art. $5^{\circ}$, parágrafo $2^{\circ}$ do texto constitucional, ao declarar que "os direitos e garantias expressos nesta Constituição não excluem outros decorrentes do regime e dos princípios por ela adotados, ou dos tratados internacionais em que a República Federativa do Brasil seja parte", reconhece explicitamente o conceito de bloco de constitucionalidade amplo. Em outras palavras, os tratados de direitos humanos passam a integrar o bloco de constitucionalidade antes referido, uma inovação trazida pela Constituição Cidadã. Nesta esteira, conforme adverte a doutrina, "ao prescrever que 'os direitos e garantias expressos na Constituição não excluem outros direitos decorrentes dos tratados internacionais', $a$ contrario sensu, a Carta de 1988 está a incluir, no catálogo de direitos constitucionalmente protegidos, os direitos enunciados nos tratados internacionais em que o Brasil seja parte. Esse processo de inclusão implica a incorporação pelo Texto Constitucional de tais direitos. Ao efetuar a incorporação, a Carta atribui aos direitos internacionais uma natureza especial e diferenciada, qual seja, a natureza de norma constitucional. Os direitos enunciados nos tratados de direitos humanos de que o Brasil é parte integram, portanto, o elenco dos direitos constitucionalmente consagrados. Essa conclusão advém ainda de interpretação sistemática e teleológica do Texto, especialmente em face da força expansiva dos valores da dignidade da pessoa humana e dos direitos fundamentais, como parâmetros axiológicos a orientar a compreensão do fenômeno constitucional." (Piovesan, 2013, p. 113).

11 Conforme o Ministro Celso de Mello, em decisão proferida no julgamento da ADI no 514-PI, o bloco de constitucionalidade pode ser traduzido como o conjunto de normas que pode servir de parâmetro para fins de controle de constitucionalidade.

12 CARVAlHO, Feliciano de. Teoria do Bloco de Constitucionalidade. Theory of Constitucionality Block. Disponível em: http://www.publicadireito.com.br/artigos/?cod=2b4830a2f3347c33, acesso em 02/05/2015.

13 Entrariam aqui, por exemplo, as Emendas Constitucionais, os direitos implícitos, os tratados internacionais de direitos humanos e as súmulas vinculantes. (CARVALHO, Feliciano de. Teoria do Bloco de Constitucionalidade. Theory of Constitucionality Block. Disponível em: http://www.publicadireito. com.br/artigos/?cod=2b4830a2f3347c33, acesso em 02/05/2015.) 
No mesmo sentido, Antônio Augusto Cançado Trindade sustenta que o parágrafo $2^{\circ}$ do art. $5^{\circ}$ da Constituição de 1988 acrescentou direitos e garantias expressos em tratados internacionais de proteção dos direitos humanos ao elenco de direitos constitucionalmente consagrados, o que denota ser "alentador que as conquistas do direito internacional em favor da proteção ao ser humano venham a projetar-se no direito constitucional, enriquecendo-o, e demonstrando que a busca de proteção cada vez mais eficaz da pessoa humana encontra guarida nas raízes do pensamento tanto internacionalista quanto constitucionalista." (Cançado Trindade, 1991, p. 631).

Sem embargo, é necessário esclarecer que não somente os tratados de direitos humanos que passaram pelo rito rígido determinado pelo artigo $5^{\circ}$, parágrafo $3^{\circ}$ da Constituição Federal, inserido pela Emenda Constitucional no 45/2004, integram este bloco. Claro está, e aqui não se encontram maiores dificuldades, que por terem sido aprovados no Congresso Nacional, por 3/5 dos votos dos respectivos membros, em dois turnos de votação em cada Casa Legislativa, adquirem hierarquia constitucional, razão pela qual devem ser observados quando da análise da compatibilidade de normas infraconstitucionais com os preceitos nele estabelecidos, já que servem de parâmetro de constitucionalidade (Carvalho Ramos, 2013, p. 277).

A questão adquire especial relevo com relação aos tratados de direitos humanos aprovados no Congresso Nacional, antes da Emenda Constitucional no 45/2004, ou seja, com relação aqueles textos internacionais que foram aprovados pelo Congresso Nacional em um turno de votação em cada Casa Legislativa, com maioria absoluta e náo maioria qualificada. Ainda que o STF, por maioria, entenda que esses tratados, por terem hierarquia supralegal e infraconstitucional (RExtr no 349.703-RS) não integram o bloco de constitucionalidade, adotando uma postura por demais formalista, somos da opinião de que estes tratados de direitos humanos, em razão da matéria, integram o bloco referido, independentemente de terem sido ou não aprovados pelo rito rígido introduzido pela Emenda mencionada.

Neste sentido, sustentando que os tratados de direitos humanos anteriores à Emenda Constitucional referida, são materialmente constitucionais, ${ }^{14}$ Flávia Piovesan destaca que: "a hierarquia constitucional já se extrai de interpretação conferida ao próprio art. $5^{\circ}, \$ 2^{\circ}$, da Constituição de 1988 . Vale dizer, seria mais adequado que a redação do aludido $\$ 3^{\circ}$ do art. $5^{\circ}$ endossasse a hierarquia formalmente constitucional de todos os tratados internacionais de proteção dos direitos humanos ratificados, afirmando - tal como fez o texto argentino - que os tratados internacionais de proteção de direitos humanos ratificados pelo Estado brasileiro têm hierarquia constitucional." (Piovesan, 2009, p. 18).

14 No mesmo sentido, ver HC no 96.772-8/SP, Rel, Min, Celso de Mello, julgado em 09/06/2009. 
Seguindo a mesma linha de orientação e adicionando um novo elemento ao debate, Celso Lafer destaca que "os tratados internacionais de direitos humanos anteriores à Constituição de 1988, aos quais o Brasil aderiu e que foram validamente promulgados, inserindo-se na ordem jurídica interna, têm a hierarquia de normas constitucionais, pois foram como tais formalmente recepcionados pelo $\$ 2^{\circ}$ do art. $5^{\circ}$ não só pela referência nele contida aos tratados como também pelo dispositivo que afirma que os direitos e garantias expressos na Constituição não excluem outros decorrentes do regime e dos princípios por ele adotados." (Lafer, 2005, p. 17).

Como corolário lógico desse raciocínio, podemos ainda trazer à colação as disposiçóes constantes dos arts. $1^{\circ}$, inciso III e $4^{\circ}$, inciso II, ambos da Constituição, que preveem como princípio fundamental do nosso ordenamento jurídico a dignidade da pessoa humana, bem como a prevalência dos direitos humanos como valores regentes das relaçóes internacionais, respectivamente. Desta feita, "a partir do momento no qual a Constituição Federal da República Federativa do Brasil erigiu como norma-fundamento a dignidade da pessoa humana no Art. $1^{\circ}$, III, e de modo expresso asseverou a prevalência dos direitos humanos nas relações externas do Estado brasileiro no Art. 4º, II, resta clara esta hierarquia de direito na qual os direitos humanos são fator subordinante. Entender que as normas internacionais reconhecidas pelo Brasil sobre direitos humanos são inferiores à Constituição Federal, é trair o espírito constitucional que fez questão de tratar da prevalência desses direitos em relação aos demais, além de elencá-los como norma fundamento a partir da dignidade da pessoa humana.” (Carvalho, 2015).

Além disso, por que somente a Convenção Internacional sobre os Direitos das Pessoas com Deficiência e seu Protocolo facultativo, assinados em Nova York, em 30 de março de 2007, internalizados ao ordenamento jurídico pelo Decreto no 6.949, de 25 de agosto de 2009, seriam os únicos tratados de direitos humanos com hierarquia constitucional em nosso sistema jurídico? Somente porque seguiram a formalidade instituída pela Emenda Constitucional 45/2004? O Pacto de San José da Costa Rica ou Convenção Americana de Direitos Humanos, o Protocolo de San Salvador sobre direitos econômicos, sociais e culturais, que o complementa, entre tantos outros tratados que estabelecem direitos e garantias ao cidadão, ${ }^{15}$ merecem hierarquia infraconstitucional, que os exclui do bloco de constitucionalidade, somente por não terem seguido o rito rígido de aprovação no Congresso Nacional, estabelecido pela Emenda referida? Estes tratados, aprovados antes de 2004, são menos importantes que a Convenção mencionada? Como fica a efetivaçáo do princípio da dignidade da pessoa humana? Parece-nos claro que seguir essa orientaçáo é menoscabar e desprestigiar a relevância dos direitos humanos nas relaçóes internas e

15 Sobre os instrumentos especiais de proteção dos direitos humanos ver: AMARAL JÚNIOR, Alberto do. Curso de Direito Internacional Público. 5a ed. São Paulo: Atlas, 2015. pp. 515-519. 
internacionais, dando demasiada ênfase a um critério formal, em detrimento da questão material, do conteúdo a ser tutelado.

Por fim, e apenas para incitar o debate, trazemos à colação o pensamento de Bidart Campos, grande constitucionalista argentino, para quem "la interpretación coherente y de buena fe que el derecho internacional merece, parece darnos razón: no es congruente que una constitución reconozca o admita el ingreso del derecho internacional, y le niegue supremacía respecto de ella misma. ¿Qué clase de recepción condicionada es ésta: se reconoce, pero se lo infraconstitucionaliza? No le vemos lógica, porque es aceptar primero una cosa, y de inmediato introducir excepciones reñidas con el principio general. La constitución vendría a enunciar algo como esto: acato, incorporo y reconozco en el derecho interno al derecho internacional, pero no a su principio básico que le atribuye la primacía por sobre mí; en consecuencia, lo acato, incorporo y reconozco, pero por debajo de mí y, en todo caso, sólo por arriba de las leyes" ${ }^{\prime \prime} \ldots$

\section{Conclusões}

O avanço do Direito Internacional, impulsionado pelo aprofundamento das relaçóes internacionais, incentiva o profundo diálogo entre as decisóes internas e as diretrizes internacionais. Há cada vez mais temas que envolvem a atuação conjunta de vários Estados, o que leva à internacionalização do direito, que, em síntese, significa a transferência para o direito internacional de temas que antes eram restritos à ordem interna.

O judiciário brasileiro se posicionou no sentido de que se adotou no país o sistema dualista, com tratados hierarquicamente posicionados como lei federal, com tratamento especial para os tratados de direitos humanos, muito embora faça uma diferenciaçáo, sob nossa perspectiva incorreta, entre tratados de direitos humanos aprovados antes e depois da Emenda Constitucional no 45, atribuindo somente a aqueles que passaram pela aprovação em dois turnos, por 3/5 dos votos dos respectivos membros de cada Casa Legislativa do Congresso Nacional a hierarquia de norma constitucional, autorizando-os a integrar o bloco de constitucionalidade, em sentido amplo.

16 BIDART CAMPOS, Germán J. El Derecho de la Constitución y su Fuerza Normativa. Buenos Aires: Ediar, 1995. p. 462. Segue o autor: "Cuando una constitución incluye alguna cláusula de reconocimiento, aceptación, acogimiento o respeto a los principios o a los tratados, con esa misma cláusula está aceptando y acatando la norma internacional que subordina todo el derecho interno al derecho internacional. $\mathrm{Si}$ luego define la supremacía de la constitución respecto de él, incurre en una contradición consigo misma $o$, al menos, en una incongruencia, porque niega la jerarquía que el proprio derecho internacional se atribuye como principio o norma general de su ordenamiento. La contradicción no se redime por decir - con acierto - que la constitución es la fuente primaria del orden jurídico estatal y que, como tal, escalona jerárquicamente sus distintos planos según decisión propia. Y no se redime porque sigue siendo incongruente que si se asume dentro del derecho interno al producto de la fuente internacional, se lo haga desvirtuando el principio básico del derecho internacional, que es el de su primacía." (Idem, p. 463.) 
Nossa proposta, tendo em vista a necessidade de efetivação do princípio da dignidade da pessoa humana e da irrestrita proteção dos direitos humanos, vai no sentido de que os tratados de direitos humanos aprovados antes da Emenda referida, igualmente devem ter hierarquia constitucional em razáo da matéria abordada, integrando, por consequência, o bloco referido, para fins de parâmetro de constitucionalidade

Neste sentido, para finalizar e dar destaque ao diálogo de fontes (Amaral Júnior, 2009, p. 102) e de cortes, resgatamos as palavras do professor Antônio Augusto Cançado Trindade, para quem: "os tratados de direitos humanos beneficiam diretamente os indivíduos e grupos protegidos. Cobrem relações (dos indivíduos frente ao poder público) cuja regulamentação era outrora o apanágio do direito constitucional. E diversas Constituiçôes modernas, a seu turno, remetem expressamente aos direitos consagrados nos tratados de direitos humanos (...), a um tempo revelando nova postura ante a questão clássica da hierarquia normativa dos tratados internacionais vigentes assim como concedendo um tratamento especial ou diferenciado também no plano do direito interno aos direitos e garantias individuais internacionalmente consagrados (...). Regendo a mesma gama de relaçóes, dos indivíduos ante o Estado, o direito internacional e o direito interno apontam aqui na mesma direção, coincidindo no propósito básico e último de ambos da proteção do ser humano." (Cançado Trindade, 2015).

No entanto, a postura majoritária do STF com relação à hierarquia dos instrumentos internacionais referidos não incentiva os juízes brasileiros a buscarem o diálogo das cortes, para encontrar a interpretação dada pelos tribunais internacionais aos tratados de direitos humanos, de forma a superar a simples análise da hierarquia de fontes. Essa carência permite que se perpetue a situação em que por mais que se discuta, na doutrina, a posição hierárquica do tratado e a interação entre a norma interna e internacional, a posição jurisprudencial adotada, por mais progressista que possa ser, é muitas vezes inócua, pois não dialoga com os tribunais internacionais, reais intérpretes dos tratados, fazendo surgir a interpretação nacional do tratado, desvinculada dos compromissos que o Estado assumiu na esfera internacional.

\section{Referências}

AMARAL JÚNIOR, Alberto do. Curso de Direito Internacional Público. $5^{\mathrm{a}}$ ed. São Paulo: Atlas, 2015.

AMARAL JÚNIOR, Alberto do. “El 'diálogo' de las fuentes: fragmentación y coherencia en el derecho internacional contemporáneo." In: Academia. Revista sobre Enseñanza del Derecho. No 13. 2009.

BALLADORE-PALLIERI, Giorgio. Diritto Internazionale Pubblico. Milano: Giuffrè, 1962. 
BARILE, Giuseppe. Diritto Internazionale e Diritto Interno. Milano: Giuffrè, 1957.

BIDART CAMPOS, Germán J. El Derecho de la Constitución y su Fuerza Normativa. Buenos Aires: Ediar, 1995.

BROWNLIE, Ian. Principles of Public International Law. 4th. ed. Oxford: Clarendon Press, 1990.

BUERGENTHAL, Thomas. Self-Executing and Non-Self-Executing Treaties in National and International Law. Recueil Des Cours. 1992.

CANÇADO TRINDADE, Antônio Augusto. A Proteção Internacional dos Direitos Humanos: fundamentos juridicos e instrumentos básicos. São Paulo: Saraiva, 1991.

CANÇADO TRINDADE, Antônio Augusto. Direito Internacional e Direito Interno: sua interação na proteção dos direitos humanos. Disponível em: http://pge.sp.gov.br/centrodeestudos/bibliotecavirtual/instrumentos/introd.htm, acesso em 04/05/2015.

CARVALHO, Feliciano de. A natureza juridica constitucional de todos os tratados internacionais de direitos humanos: análise da supralegalidade e da inconsciência do Supremo Tribunal Federal brasileiro. Disponível em: http://www.publicadireito.com.br/artigos/?cod=e19099504769f3f7, acesso em 03/05/2015.

CARVALHO, Feliciano de. Teoria do Bloco de Constitucionalidade. Theory of Constitucionality Block. Disponível em: http://www.publicadireito.com.br/artigos/?co$\mathrm{d}=2 \mathrm{~b} 4830 \mathrm{a} 2 \mathrm{f3347c33}$, acesso em 02/05/2015.

CARVALHO RAMOS, André. O Diálogo das Cortes: O Supremo Tribunal Federal e a Corte Interamericana de Direitos Humanos. In: AMARAL JÚNIOR, Alberto do; JUBILUT, Liliana Lyra. (Org.) O STF e o Direito Internacional dos Direitos Humanos. São Paulo: Quartier Latin, 2009, p. 805-850.

CARVALHO RAMOS, André de. A pluralidade das ordens jurídicas e a nova centralidade do Direito Internacional (Boletim da Sociedade Brasileira de Direito Internacional (Boletim da Sociedade Brasileira de Direito Internacional Ano XCVIII - Agosto/ Dezembro 2013 - No 119-124 - V.1). Boletim da Sociedade Brasileira de Direito Internacional, v. 1, 2013.

CARVALHO RAMOS, André de. Teoria geral dos direitos humanos na ordem internacional. $3^{\mathrm{a}}$ ed, Saraiva: São Paulo, 2013.

COMPARATO, Fábio Konder. O Papel do Juiz na Efetivação dos Direitos Humanos. In: Publicação Especial em Comemoração aos 10 anos de Fundação da Associação Juizes para a Democracia. Direitos Humanos - Visões Contemporâneas. São Paulo: Associação Juízes para a Democracia, 2001.

CONFORTI, Benedetto. Diritto Internazionale. 8a. Ed. Napoli: Editoriale Scientifica, 2010. 
DINH, Nguyen Quoc; DAILLIER, Patrick, \& PELLET, Alain. Direito Internacional Público. Tradução de Vítor Marques Coelho. Lisboa: Fundação Calouste Gulbenkian, 1999.

ENGISCH, Karl. Introdução ao Pensamento Jurídico. 7. ed. Lisboa: Fundação Calouste Gulbenkian, 1996.

FARIA, José Eduardo. O direito na economia globalizada. $1^{\text {a }}$ Ed. $4^{\text {a }}$ Tiragem. São Paulo: Malheiros, 2004.

JENNINGS, Robert Y. General Course on Principles of International Law. Recueil Des Cours. 1967.

KELSEN, Hans. Les Rapports de Système entre le Droit Interne et le Droit International. Recueil Des Cours. 1926.

KUMM, M. Constitutional Democracy Encounters International Law: Terms of Engagement [Internet]. Rochester, NY, 2009: Social Science Research Network; Report No.: ID 952023. Disponível em: http://papers.ssrn.com/abstract=952023

LAFER, Celso. A Internacionalização dos Direitos Humanos: Constituição, Racismo e Relaçóes Internacionais. Barueri: Manole, 2005.

MALANCZUK, Peter. Akehurst's Modern Introduction to International Law. 7th. ed. London: Routledge, 1998.

MELLO, Celso D. Albuquerque. Direito Constitucional Internacional. 2. ed. Rio de Janeiro: Renovar, 2000.

MENÉNDEZ, Fernando M. Mariño. Derecho Internacional Público - Parte General. 2. ed. Madrid: Editorial Trotta, 1995.

MORELLI, Gaetano. Nozioni di diritto internazionale. Padova: Cedam, 1955.

NEVES, Marcelo. Transconstitucionalismo. 1. ed. São Paulo: WMF Martins Fontes, 2009.

PIOVESAN, Flávia. Direitos Humanos e o Direito Constitucional Internacional. $14^{\mathrm{a}} \mathrm{ed}$. São Paulo: Saraiva, 2013.

PIOVESAN, Flávia. Temas de Direitos Humanos. 3a ed. São Paulo: Saraiva, 2009.

REUTER, Paul. Droit International Public. Paris: Presses Universitaries de France; 1973 e ROUSSEAU, Charles. Droit International Public - 5 vol. Paris: Sirey, 1970.

SHAW, Malcom N. International Law. 3a ed. Cambridge: Grotius Publications. 1995.

SILVA, Virgílio Afonso da. "O STF e o controle de constitucionalidade; deliberação, diálogo e razão pública”. In: Revista de Direito Administrativo. No 250. 2009

SOARES, Guido Fernando Silva. Curso de Direito Internacional Público. 2. ed. São Paulo: Editora Atlas, 2004. 
STEWART, R. B.; SANCHEZ BADIN, M. R. The World Trade Organization: Multiple Dimensions of Global Administrative Law. International Journal of Constitutional Law, v. 9, n. 3-4, doi: 10.1093/icon/mor051, 2011.

TRIEPEL, Karl Heinrich. Droit International et Droit Interne. Paris: Pédone, 1920.

VIEIRA, Luciane Klein. "La incorporación de los tratados internacionales al orden jurídico interno de Brasil”. In: NEGRO, Sandra (Dir.) Evolución Jurídico-Institucional. Derecho de la Integración. Manual. Parte II América-África. Buenos Aires: BdeF, 2012. 